\title{
Teaching the Art and Science of Storytelling in Crafting an Authentic Brand Story
}

\author{
Justine Haigh \\ George Fox University
}

\begin{abstract}
Oregon's non-profit sector consists of 31,224 not for profit organizations. The vast majority of these organizations are small in size but play a vital role in serving Oregon's diverse community needs ("Why nonprofits are important," 2017). In order to stand out in a crowded market place, organizations that take the time to consider their authentic brand value will survive in the long run. The paper describes how a young Portland-based non-profit organization, FIDGETECH, worked with an MBA marketing class at George Fox University to create a competitive advantage through adopting a digital brand storytelling approach.
\end{abstract}

\section{INTRODUCTION}

The research was conducted by a full-time MBA Marketing Management class at George Fox University in Newberg, Oregon who carried out the project as part of an in-class brand strategy assignment. The course professor and FIDGETECH president, shared in-depth details about the nonprofit and provided strategic guidance in the art and science of crafting an authentic brand story.

The primary distinctive of this project was the explicit use of students to inform the process that will lead to the development of a promotional video for FIDGETECH. The MBA-level marketing course was an integral part of the storytelling approach, where the students highlighted the essential components to be assimilated into FIDGETECH's final brand story. The students were able to work on a real-time project that permitted experience with the course brand strategy content in a deep and meaningful manner.

The purpose of the paper is to discuss the procedures taken and to make suggestions and recommendations for other marketing or branding courses seeking to adopt a similar method. Justine Haigh who taught the course, holds a $\mathrm{PhD}$ in narrative consumer behavior and is highly engaged in the power of storytelling, with a driving commitment to make a lasting difference in people's lives. One of Haigh's key passions is helping her non-profit FIDGETECH, assist young adults with autism find creative and meaningful long-term employment. As the President of FIDGETECH, Haigh's concern for this work spans from firsthand experience having an adult autistic son, Daniel.

\section{POSITION PAPER PRESENTATION}

The presentation will cover the following elements:

The storytelling approach will be discussed, including how the project was facilitated in-class, the students' role in crafting the narrative, as well as how the local non-profit plans to develop a promotional 
video that best portrays the final brand "story". An important focus for detailing this procedure is to ensure the delivery of a message consistent with the purpose, vision, and mission of the non-profits authentic brand. Overall, the presentation will provide a hands-on guide for leveraging the power of storytelling for in-class projects or other branding story exercises. In response to the overwhelming number of non-profits in the greater Portland area, as well as what Edelman (2018) describes as a valuesdriven brand era, the importance of this approach cannot be over-emphasized. ("Edelman Earned Brand," 2018).

\section{REFERENCES}

Edelman Earned Brand (2018). Retrieved from https://www.edelman.com/sites/g/files/aatuss191/files/201810/2018_Edelman_Earned_Brand_Global_Report.pdf

Why nonprofits are important (2017). Retrieved from

https://nonprofitoregon.org/sites/default/files/uploads/file/2017\%20Oregon\%20Nonprofit $\% 20$ Eco nomic $\% 20$ Snapshot_final.pdf 